\title{
Feasibility of Accessibility in Sekayu Village Semarang
}

\author{
Sepli Yandri ${ }^{1}$, Yeptadian Sari ${ }^{1}$, Dedi Hantono ${ }^{1}$ \\ ${ }^{1}$ Department of Architecture, Faculty of Engineering, Universitas Muhammadiyah Jakarta, Indonesia \\ sepli.yandri@umj.ac.id
}

\begin{abstract}
In urban areas, accessibility is one of significant factors to increase the economic growth. Accessibility is very important in improving community welfare. Infrastructure can also cause economic growth. Therefore, proper road infrastructure is useful for good accessibility. Development of transportation and network of road are useful to facilitate the activities in the village. As one of the urban areas in Semarang city, Sekayu village needs good accessibility as well, because Sekayu is a historic village. In this village, many old buildings have the potential to invite tourists to come to the city. Therefore, this study aims to assess the suitability of accessibility in Sekayu Village.
\end{abstract}

(c) 2021 IJBESR. All rights reserved.

Keywords: urban, accessibility, roads, achievements, villages.

\section{Introduction}

Qualified township can be seen from the society's role. This is seen from the handling of the environment, such as improving the village, renovating the village and improving the quality of the environment [1].

The development of Semarang City is always related to the problems and existence of villages that are developing following the growth of the city. One of the villages located in the city of Semarang is Kampung Sekayu. the Sekayu is part of Semarang. This village was not built deliberately by urban designers but planned according to the needs of its inhabitant. typically, in a village development will involve dramatic institutional changes and government restructuring [2].

Infrastructure is one of the requirements necessary to improve the welfare of society. Infrastructure is also a wheel of sustainable economic growth. Construction and operation of urban sustainability depends on infrastructure that could be used. Understanding the resilience and vulnerability of critical infrastructure to the security of the city [3]. This is because every aspect of life is always related to infrastructure, such as means of transportation, clean water needs, sanitation, processing waste, roads, energy etc.

Future city development is based no more on infrastructure growth but on its effectiveness and quality which may be achieved only by installing newest technologies and implementing strategic management. As what Snieška [4] said that the availability of good infrastructure is the main thing in increasing investment, economic growth, and equitable development.Lack of infrastructure is one obstacle in improving investment in Indonesia. Therefore, the availability of infrastructure networks is very important in facilitating trade and investment activities.Attention to infrastructure in Sekayu village in Semarang is 
considered important to overcome economic disparities.

The infrastructure discussed in this study is the existence of road infrastructure in Sekayu village of Semarang. increases in road width can help mitigate congestion,improve fuel efficiency, and thus reduce emissions. On the contrary, extending roads to new or unconnected areas is likely to bring more vehicles onto the roads and extend average driving time [5].

\section{Material and Methods}

The method used in this paper is a study of analysis description, which describes and analyzes the area, related to the accessibility contained in Sekayu Semarang. Descriptive analysis used in this study is an explorative descriptive analysis that aims to describe the state of something or the status of a phenomenon.

\subsection{Infrastructure}

According to Grigg [5] infrastructure is a physical system that provides transportation, irrigation, drainage, buildings, and other public facilities, which are needed to meet basic human needs both social needs and economic needs. This definition refers to infrastructure as a system and in an infrastructure system are the parts in the form of facilities and infrastructure that are inseparable from each other. This is because the infrastructure in a system supports the social system and economic system as well as being a liaison with the environmental system. The availability of infrastructure has an impact on the social system and economic system in the community. Therefore, infrastructure needs to be understood as a basic basis for policymaking.

\subsection{Accessibility}

According to Black [6] accessibility is a measure of the convenience or ease of land use location interacting with one another, and the ease or difficulty of the location is achieved through transportation. According to the Maghreb, that accessibility is a measure of convenience that includes time, cost, and effort in moving between places or regions of a system [7].One variable that can be stated whether the level of accessibility is high or low can be seen from the number of network systems available in the area. The more network systems available in the area, the easier the accessibility that is obtained, and vice versa, the lower the level of accessibility obtained, the more difficult the area is reached from other areas [8].

The level of regional accessibility can also be measured based on several variables, namely the availability of the road network, the amount of transportation equipment, the length, the width of the road, and the quality of the road. Besides that, determining the level of access is the pattern of land use regulation. Diversity in the arrangement of public facilities between one region and another. Such a variety of patterns of regulation of public facilities occurs due to the location of public facilities that are geographically separated and different in type and intensity of activities. This condition makes the spread of land in an area of uneven (heterogeneous) and the distance factor is not the only element that determines the level of accessibility [9].

\subsection{Road Insfrastructure}

According to Law Number 38 of 2004 [10], roads are land transportation infrastructures which cover all parts of the road, including complementary buildings and equipment intended for traffic, which is at ground level, above ground level, below ground level and/or water, and above the water surface, except 
railroad tracks, lorry roads and cable roads. Based on the designation road splits into two:

1. Public roads: intentionally made and intended for public traffic.

2. Special roads: roads built by agencies, business entities, individuals, or community groups for their own interests. So that special road is not intended for public traffic in the context of the distribution of goods and services.

The implementation of public roads is carried out by prioritizing the construction of road networks in production centers as well as roads that connect production centers to marketing areas. The implementation of the road is directed to strengthen national unity so that it can reach remote areas.

Roads as part of transportation infrastructure have an important role in the economic, sociocultural, environmental, political, defense and security fields, and are used for the greatest prosperity of the people. The road as a distribution infrastructure for goods and services is the lifeblood of the life of the people, nation, and state. The road which is a unified road network system connects and binds the entire territory of the Republic of Indonesia.

the population distribution and road network have a strong correlation in city evolution because population expansion can incur a significant travel requirement, which will stimulate the growth of the road network. Similarly, the growth of the road network will accelerate population expansion [11].

\subsubsection{The Parts of the road}

The parts of the road according to Law number 34 include the road to the benefits of the road, the space owned by the road, and the road supervision room
- Road benefit space includes the road body, roadside channel, and safety threshold.

- Road space includes the benefits of roads and certain lines of land outside the road to benefit the road.

- The road supervision room is a certain space outside the road that is under the supervision of the road operator.

\subsubsection{Grouping of Roads}

Public roads according to their status are grouped into national roads, provincial roads, district roads, city roads, and village roads.

- National roads are arterial roads and collector roads in the primary road network system that connects between provincial capitals, and national strategic roads, as well as toll roads.

- Provincial roads are collector roads in the primary road network system that connects provincial capitals with district/city capitals or between district/city capitals, and provincial strategic roads.

- District roads are local roads in the primary road network system that connects district capitals with sub-district capitals, between sub-district capitals, district capitals with local activity centers, between local activity centers, and public roads in the secondary road network system in the district area, and district strategic roads

- $\quad$ City roads are public roads in a secondary road network system that connects between service centers in the city, connecting service centers with the parcel, connecting between personnel, and 
connecting the centers of settlements within the city.

- Village roads are public roads that connect the area and/or between settlements within the village, as well as environmental roads.

From the explanation of the grouping of roads according to Law No. 34 concerning roads, the roads in the Sekayu village of Semarang City are classified as rural roads, namely intersettlement roads in the village or a village.

Public roads according to their functions are grouped into arterial roads, collector roads, local roads, and environmental roads.

- The arterial road is a public road that serves to serve the main transportation with the characteristics of long-distance travel, high average speed, and the number of access roads is limited efficiently.

- Collector road is a public road that serves to transport collectors or divides with the characteristics of moderate distance travel, moderate average speed, and the limited number of access roads.

- Local roads are public roads that function to serve local transport with characteristics of short distance travel, low average speed, and the unlimited number of access roads.

- Environmental pathis a public road that serves to serve environmental transport with characteristics of short distance travel, and low average speed

\section{Arterial Roads}

The primary arterial road is a road that connects between first level cities adjoining or connecting one level city to the second level city. If it is viewed from the role of the road, the requirements that must be met by Primary Arterial roads are:

a. Plan speed $>60 \mathrm{~km} /$ hour

b. The width of the road $>8.0 \mathrm{~m}$

c. Road capacity is greater than the average traffic volume.

d. The access road is limited efficiently so that the speed of the plan and road capacity can be achieved

e. Must not be disturbed by local activities, local traffic.

f. The primary road is not interrupted even though entering the city.

The secondary arterial road is a road that connects the primary area with the secondary area one or connects the secondary area one with the other secondary area or secondary area one with the second secondary area.

When viewed from the role of the road, the requirements that must be met by secondary arterial roads are:

1. Plan speed $>30 \mathrm{~km} /$ hour

2. The width of the road $>8.0 \mathrm{~m}$

3. Road capacity is greater or equal to the average traffic volume

4. Don't be disturbed by slow traffic.

\section{Collector roads}

The primary collector road is the road that connects the second city with the second level city, or the first level city with the third level [12]. If it is viewed from the role of the road, the requirements that must be fulfilled by the primary collector road are::

1. Plan speed $>40 \mathrm{~km} /$ hour

2. The width of the road $>7.0$

3. Road capacity is greater or equal to the average traffic volume. 
4. The access road is limited efficiently so that the speed of the plan and the capacity of the road are not disturbed.

5. Must not be disturbed by local activities, local traffic.

6. The primary collector road is not interrupted even though entering the city area..

Secondary collector road is a road linking the second secondary area with other secondary areas or connecting the second secondary area with the third secondary area..

If viewed from the role of the road, the requirements that must be met by the secondary collector road are:

1. Plan speed $>20 \mathrm{~km} /$ hour

2. Road width $>7 \mathrm{~m}$

\section{Local Roads}

The primary local road is the road that connects the first level city with the parcel (residential area), the second level city with the parcel, the third level city with the other third level city, the third level city with the lower level city [12].

If viewed from the role of the road, the requirements that must be met by the primary local road are:

1. Plan speed $>20 \mathrm{~km} /$ hour

2. Road body width $>6.0 \mathrm{~m}$

3. Primary local roads are not interrupted even though entering the village

Secondary local roads are roads that connect secondary areas first to housing, or second secondary areas with housing, or third secondary areas and so on with housing.

If viewed from the role of the road, the requirements that must be met by secondary local roads are:

\section{Plan speed $>10 \mathrm{~km} /$ hour}

\section{Road width $>5.0 \mathrm{~m}$}

\section{Enviromental Roads}

The environmental road is a public road that serves to serve the environmental transportation with features that are for shortdistance travel, and low average speed.

\section{Results and Discussions}

\subsection{Transportation}

As one of the densely populated villages located in the middle of the city, the highway on the edge of the village is crossed by various city transportation, such as city transportation. However, access to enter Sekayu is a mode of transportation that can only be rickshaw and motorcycle taxi, due to the narrow village alleys to be entered into four-wheeled vehicles.

\subsection{Roads}

From the explanation of the theories discussed, the roads in Sekayu village are included in the classification of Secondary Local roads and environmental roads.
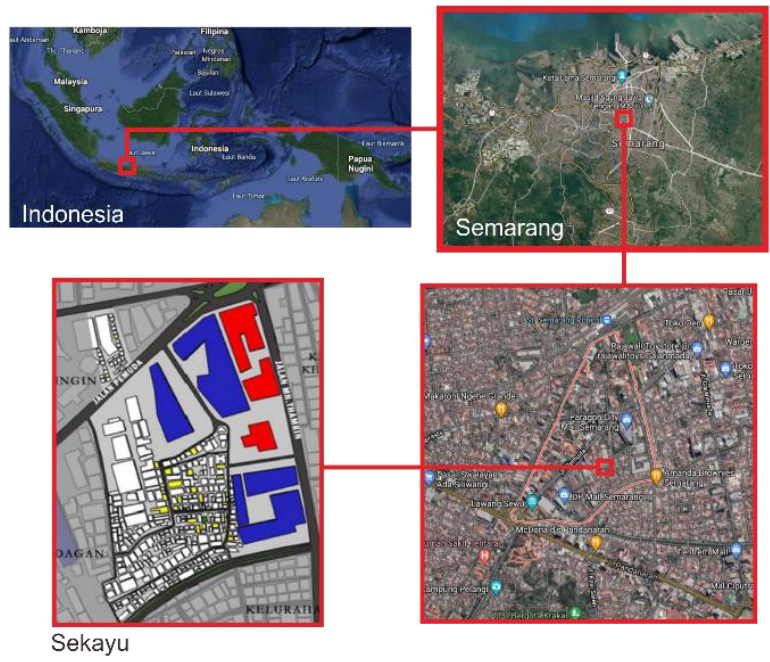

Source: (Google Map and Analysis, 2018) Figure 1. Map of Sekayu village 
transportation with characteristics that are for

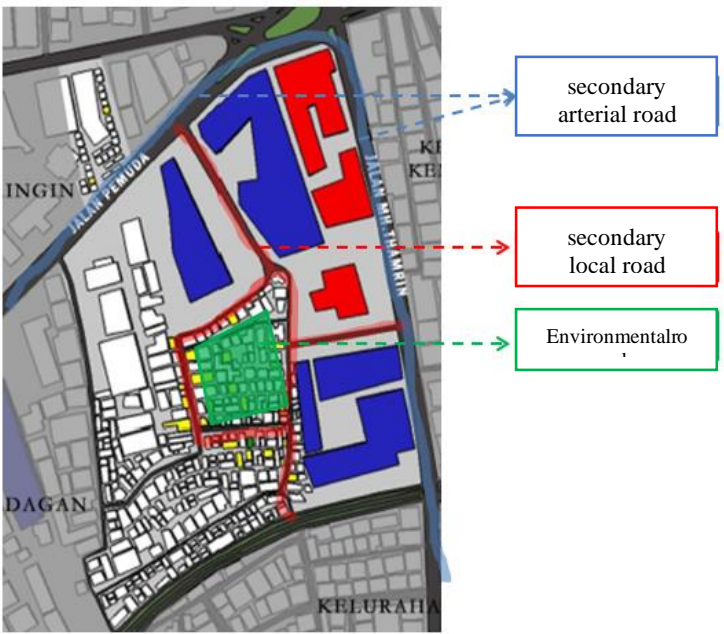

Source : (Analysis of 2018 and Surveys, 2018) Figure 2. Analysis of the classification of roads in Sekayu village

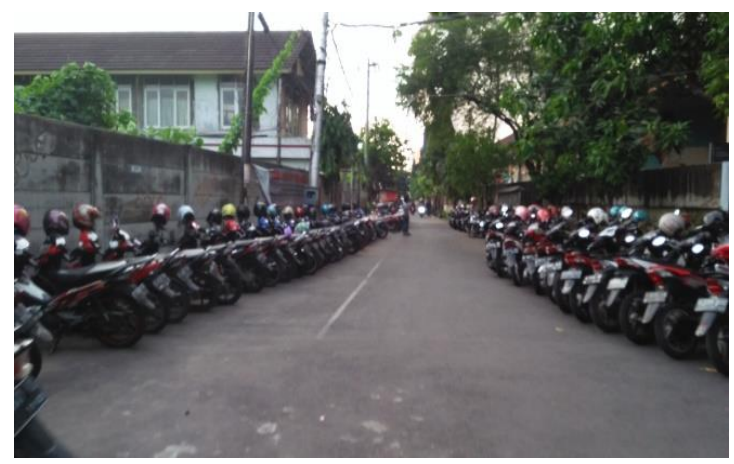

Source : (Author, 2018)

Figure 3. Changes in the function of the road in the village to park the vehicle

If viewed from the role of the road, the requirements that must be met by secondary local roads are:

1. Plan speed $>10 \mathrm{~km} /$ hour

2. Road width $>5.0 \mathrm{~m}$

With the requirement of a road size of $5 \mathrm{~m}$ wide, the secondary local road in Sekayu village area is located on the edge of the village which is quite large in size and can still be accessed by a 4-wheeled vehicle. small with low speed where roads like this are included in the Environmental Road which is a public road that serves to serve the environmental short distance travel, and low average speed.

In the township, there is a fairly large road in the gate area when entering the village, but the road has changed its function to become a sidewalk trading location and becomes a parking area for two-wheeled vehicles, this is caused by a modern shopping center building which stands right next to the village.

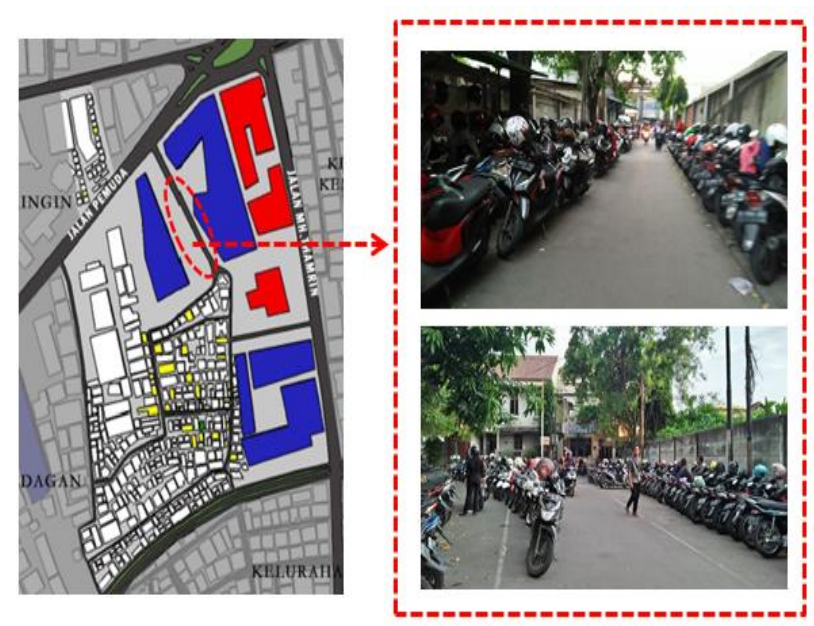

\section{Source : (Author, 2018)}

Figure 4. Changes in the function of the road in the village to park the vehicle

the change in the function of the road into a parking area makes the roads in the neighborhood become less comfortable. village access is disturbed.

In addition to the street phenomenon that changes its function to parking for twowheeled vehicles, in Sekayu village there is also a road that the vehicle should be able to travel comfortably and freely but because there are electricity poles that are right in the middle of the road causing access to the village to be interrupted even to drive a vehicle two wheels for riders who are not used to driving in a village must be focused and careful to avoid accidents. 


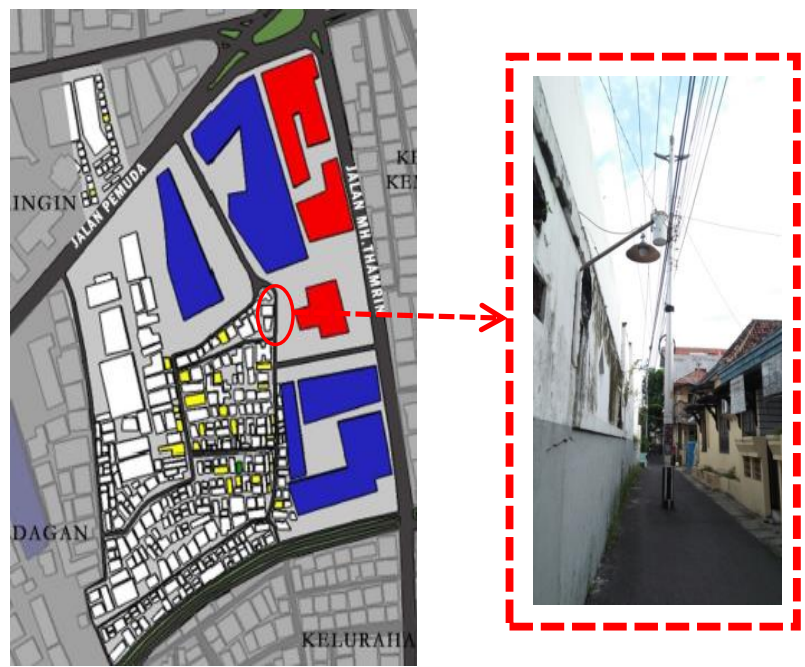

Source: (Author, 2018)

Figure 4. Electric poles in the middle of the road causing access to be disturbed

\section{Conclusion}

From the results of the survey and the authors' analysis of the accessibility of Sekayu village, it was concluded that the road as accessibility in the Sekayu village was found, namely the existence of secondary local roads around the village and neighborhood roads in the village. but phenomena in the field found things that interfere with the feasibility of accessibility on secondary local roads such as changes in road space needed to park vehicles which causes secondary local roads to access the village to be disrupted, besides the existence of electricity poles that stand in the middle of the road also interfere with accessibility in Sekayu village, especially for motorized vehicles. But with all the shortcomings and advantages, the roads and alleys that exist in Sekayu village settlements have been able to accommodate the needs of the residents. This is indicated by various activities that can be done along the alley in the Sekayu village settlement area and the condition of the circulation lane in the alley that is quite good. However, the existence of these various activities will also cause problems, especially related to the smooth circulation of vehicles and the safety of children playing.

As one of the densely populated villages located in the middle of the city, the highway on the edge of the village is crossed by various city transportation, such as city transportation. But to access the Sekayu village, the mode of transportation can only enter motorbikes, due to the narrow village alleys to be entered by cars

In terms of clean water infrastructure, the Sekayu village has now been facilitated by the city government, the water channel is located in several points in the corner of the village which can be used for the needs of the villagers. Sanitation or sewerage is overcome by closing the ditch with pavement in anticipation that the waste does not enter the area, but the cover on the ditch is still not evenly distributed, in some angles, there are still some gutters filled with garbage, especially sewers that are not covered with pavement.

The existence of Sekayu villages in the middle of the city makes the electricity infrastructure in this village well facilitated. There are always lights in the village's houses in every house that illuminates the village's streets, so the village will be bright even at night.

\section{References}

[1] Yuliastuti, Nany. Saraswati, Novi. Environmental Quality in Urban Settlement: The Role of Local Community Association in East Semarang Sub-District. Procedia - Social and Behavioral Sciences 135; 2014, P. $31-35$

[2] Guo, yan. et al. The redevelopment of peri-urban villages in the context of path-dependent land institution change and its impact on Chinese inclusive urbanization. The case of Nanhai, China. Cities 60; 2017, p. 466-475.

[3] Havko, Ján, et al. Vulnerability of the city infrastructure as a part of the resilient city concept. Procedia Engineering 192; 2017, p. 307 - 312.

[4] Snieška, Vytautas \& Zykiene Ineta. The role of infrastructure in the future city: theoretical perspective. Procedia - Social and Behavioral Sciences 156; 2014, p. $247-251$. 
[5] Luo, Zhi. et al. Urban pollution and road infrastructure: A case study of China. China Economic Review 49; 2018, p. 171-183.

[6] Black, J.A. Urban Transport Planning: Theory and Practice, London, Cromm Helm; 1981.

[6] Grigg, Neil S. Infrastructure Engineering and Management; 1988.

[7] Magribi, M. Geografi Transportasi, Post-Graduate Gajah Mada University, Yogyakarta; 1999

[8] Bintarto. City Village Interaction and Problems, Jakarta: Publisher Ghalia Indonesia; 1980.

[9] Miro, Fidel. Transportation Planning for Students, Planners and Practitioners, Jakarta: Erlangga.; 2004.

[10] Republik Indonesia. Undang-Undang Republik Indonesia Nomor 38 Tahun 2004 Tentang Jalan. Lembaran Negara Republik Indonesia Tahun 2004 Nomor 132. Presiden Ri. Jakarta.

[11] Wu, et al. City expansion model based on population diffusion and road growth. Applied Mathematical Modelling 43; 2017, p. 1-14

[12] R. Desutama. Jalan Arteri Primer, Politeknik Negeri Bandung, Bandung; 2007. 